\title{
Hvad med teaterhistorien? (What about Theatre History?)
}

\section{Edited by Erik Hvidt and Per Lykke.}

Selskabet for Dansk Teaterhistorie, Copenhagen: Multivers, 2016, 287 p.

\section{RIKARD HOOGLAND, Stockholm University}

Publications concerning theatre history are common, the subjects shift from singular productions to attempts to grasp the world history of theatre. Some of them aim to be used as textbooks at universities, others aim for a broader reading circle amongst theatre connoisseurs like biographies of famous directors or actors. When it comes to theatre history research, the aim is often twofold. Besides shedding new light on and offering interpretations of periods of theatre history, they are a ground for development and investigations of historiographic theories and methodology. But how often do we ask the question: has our contemporary theatre any use of theatre history knowledge?

The anthology Hvad med teaterhistorien? has this question as its starting point for the 15 articles and interviews. The texts are mostly based on Danish theatre history, but there are some comparisons with examples from other European countries. The answers are given not only by theatre researchers or teachers, but also by practitioners such as directors, actors, dramaturges, choreographers, and critics. Some of the practitioners have a background in theatre studies and some of the researchers have also worked as dramaturges and directors. Interestingly, some of the contributors are not of Danish origin, but work regularly in Denmark (for example German director Peter Kupke, or director Mick Gordon from Northern Ireland). These contributions offer an 
opportunity for an outsider's view on the Danish stage tradition that enrich the collection of articles.

One of the risks with such a book could be that it primarily celebrates a glorious history, but what is important here is that the authors really take advantage of the possibility to make a statement. The dancer and choreographer Dinna Bjørn's article concerns the Bournonville tradition and how it could be redefined and expanded. She analyses the way Bournonville has been danced and poses the question when it started to be a tradition. In an excellent way she presents a successful cooperation between researchers, archivists, and practitioners. The article is followed by theatre critic Anne Middelboe Christensen's article about the preservation and uses of archival resources for researching the Danish Royal Theatre's history, noting the characteristic smell from the cuttings of reviews from the daily papers. She too emphasizes the need for and possibilities with a Bournonville study centre in Copenhagen.

Dramaturge, theatre researcher, and translator Bent Holm digs into the relations between King Frederik VII, his extra private wife (!), the Ottoman Empire, and the Royal Theatre in Copenhagen. The article goes far off from the theatre auditorium to European politics and Holm concludes by noting the importance of seeing one's own history in a global perspective and questions the various historical "filtres" such as different issues of morality, gender, and sociopolitics. What he shows is that the theatrical event, both on the stage and off, can be used as a point for focalisation.

Theatre researcher Ulla Kallenbach takes up the possibility of finding new ways to analyse theatre history. Surveying a range of examples from recent books on theatre history and their different perspectives, she remarks that the willingness to expand theatre history to a global study could result in central topics in European theatre history such as Comedia dell'arte becoming peripheral and no longer a topic for deeper research. She proposes a new research perspective to connect theatre history with the cultural history of imagination in the intersection of stage performances and play scripts.

Associate professor Stig Jarl has, as a departure point, an article in the weekly cultural newspaper Weekendavisen from 2011 about the rumours that the university was going to reduce teaching in theatre history and that they no longer were interested in Danish culture. Jarl, who has an insider view from the Theatre and Performance Studies Department at Copenhagen University, maps out the developments and changes of the teaching of theatre history, a development that is similar to other western departments in the field. Firstly, the discipline has, through the years, expanded its programme towards new fields such as theatre sociology and performance analysis, where the term 'performance' also stands for a broad perspective of what events can be analysed. Secondly, the development is that theatre and performance history no longer can be restricted to the nation or western theatre. And thirdly, this expanded theatre history has to be covered with less teaching hours and meet the demands from the government that education should lead to jobs.

A number of the contributions to the book are interviews with theatre practitioners conducted by editor Per Lykke. This gives a complementary view 
on theatre history from the practitioners' side, and what use they have of their knowledge. The first is with Swedish actress Stina Ekblad who undertook her actor training in Denmark and still makes guest appearances on the Danish stage and television. She talks about the preparation work she does for a new role and that she almost takes on the role as a researcher and reads a lot of material connected to the play. As an actor who, first of all, focuses on the text, she is very sensitive when the wording is problematic and in the best cases she has had the possibility to discuss it with the translator. But she also takes up the importance that theatre history has for her main place of work, The Royal Dramatic Theatre in Stockholm, where young actors could learn from older actors from generation to generation, especially regarding the theatre's tradition of the spoken language. Ekblad questions classical plays being placed in a contemporary setting without problematizing or even understanding the consequences.

The Danish stage directors Peter Langdal and Kasper Holten seem to take the same standpoint. In their interviews, they both note the necessity of translating classical plays into a contemporary context and they highlight the importance of understanding how the play was produced and received by the original audience and "translate" situations in the play into something similar in our time. I lack here a critical analysis of how well they succeed in transforming classical plays into our contemporary society.

The theatre and opera researcher and dramaturg Magnus Tessing Schneider's article takes up the same issue when he writes about a historically informed dramaturgy. He finds that Peter Konwitschny's production of Don Juan was a modern staging that took its starting point in the opera's own challenges of eroticism, sexuality, and moral authority rooted in the late Enlightenment. He juxtaposes this example against what he calls 'postmodern stagings' in which the opera is merely material that can be used and not interpreted.

The Swedish director Staffan Valdemar Holm also talks in his interview about the importance of knowing and understanding the play's historical background. But he also gives a more playful example of reusing theatre history. When he staged Strindberg's Miss Julie in Copenhagen in 1992 with the group Nyt Skandinavisk Forsøgsteater, they also planned to publish a fictive theatre history with arranged photos from performances that had only appeared in their imaginations.

The book Hvad med teaterhistorien with its shifting perspectives on Danish theatre history gives important answers to questions such as who should write history, how can it be used adequately, and how can it be important for contemporary stagings. It gives good examples on building relations between practitioners and theorists, and opens up new ways of writing theatre histories. 